\title{
Changes in soil nematode populations indicate an annual life cycle at Cape Hallett, Antarctica
}

\author{
Gregor W. Yeates ${ }^{a, *, 1}$, Matthew B. Scott ${ }^{b}$, Steven L. Chown ${ }^{c}$, \\ Brent J. Sinclair ${ }^{d}$
}

\author{
a Landcare Research, Private Bag 11052, Palmerston North 4442, New Zealand \\ ${ }^{\mathrm{b}}$ Botany Department, University of Otago, Dunedin, New Zealand \\ ${ }^{\mathrm{C} C e n t r e}$ for Invasion Biology, Department of Botany and Zoology, Stellenbosch University, South Africa \\ ${ }^{\mathrm{d}}$ Department of Biology, The University of Western Ontario, London, Ontario, Canada N6A 5B7
}

Received 8 October 2008; received in revised form 27 January 2009; accepted 29 January 2009

KEYWORDS

Antarctic;

Nematoda;

Penguin colony;

Reproduction;

Seasonality;

Water

\begin{abstract}
Summary
Soil biological studies have suggested that generations of terrestrial nematodes in continental Antarctica may take many years. We sampled soil nematodes at three sites in the Adélie penguin colony at Cape Hallett on four dates in a two month sampling period (16 November 2002-18 January 2003). The size class distribution of over 3500 nematodes, and the occurrence of adults, indicate an annual life cycle of the bacterial-feeding Panagrolaimus davidi and Plectus murrayi, at each site. Nematode abundance ranged from 2 to $1375 / \mathrm{g}$ dry soil. Moderate temperatures and the regular presence of free water underlie this biological activity and related contribution to soil processes.
\end{abstract}

(c) 2009 Elsevier GmbH. All rights reserved.

\section{Introduction}

Soil biological studies in continental Antarctica have been concentrated in the Dry Valleys of Victoria Land (Wall et al. 2006), although there

\footnotetext{
*Corresponding author. Tel.: +6463554800; fax: +6463554801

E-mail address: gregor.yeates@gmail.com (G.W. Yeates).

${ }^{1}$ Present address: P.O. Box 1758, Palmerston North 4440, New Zealand.
}

have been collections made at various scales across much of ice-free Antarctica (e.g., Sinclair 2001; Sinclair and Sjursen 2001; Porazinska et al. 2002a; Sohlenius et al. 2004; Chown and Convey 2007; Pugh and Convey 2008). Low temperature and low available moisture are considered to severely curtail soil biological activity and thus the contributions of biota to soil biology, with some authors stating that multi-cellular soil animals may not complete their life cycles within a given year (e.g., Janetschek 1967; Overhoff et al. 1993; 
Porazinska et al. 2002b). However, significant diurnal changes in surface soil temperatures occur in Antarctic ecosystems during periods without snow cover indicating the likelihood of intermittent biological activity (e.g., Kennedy 1993; Sinclair et al. 2003). The present study represents an extension of observations on seasonal variation in soil nematodes and Collembola made in the maritime Antarctic (e.g., Spaull 1973; Burn 1984).

Soil nematodes are important constituents of below-ground biota with their activities contributing to a wide range of soil processes (Yeates et al. 2009). Soil nematode abundance and diversity are important in determining their contribution to soil processes, which have been widely studied in temperate and tropical soils. However, soil processes receive little contribution from nematodes present as eggs, encysted females or anhydrobiotic individuals (Wharton and Barclay 1993; Womersley et al. 1998) or in hot or cold deserts where lack of free water may limit nematode activity (Freckman et al. 1975; Treonis et al. 2002).

While there have been seasonal studies in the Antarctic Peninsula, field studies of nematodes in continental Antarctica have typically been based on single event sampling programmes or surveys (Yeates 1970; Sohlenius et al. 2004; Adams et al. 2006; see Andrássy 1998 and Maslen and Convey 2006 for reviews), and there have been no attempts to assess their seasonal activity. Porazinska et al. (2002b) conducted a temporal study in continental Antarctica that involved three samplings over a sixyear period. From a combination of field and laboratory studies it was suggested that the life cycle of the dominant nematode in the Dry Valleys, Scottnema lindsayae (Cephalobidae) might take as long as 20 years to complete in the field (Moorhead et al. 2002). Recent studies of the impact of a discrete climatic event and of the decline of a dominant invertebrate species in the carbon cycle have used nematode data from the McMurdo Dry Valleys (Barrett et al. 2008a, b).

This paper reports on dynamics of nematode populations in three habitats of the algal flats associated with the Adélie penguin colony at Cape Hallett, based on four sampling events during the 2002-2003 summer.

\section{Sites and sampling}

The study took place in the Cape Hallett ice-free area, a small ( $\sim 72$ ha) ice-free area in North Victoria Land Antarctica $\left(72^{\circ} 19^{\prime} \mathrm{S}, 170^{\circ} 13^{\prime} \mathrm{E}\right)$. The ice-free area consists of friable cliffs and steep blocky scree slopes, and low undulating moraines and penguin mounds. Approximately half the icefree area is occupied by an Adélie penguin (Pygoscelis adeliae) colony, characterised by a compact guano pavement that does not support a terrestrial plant community (SCAR 2003). A network of broad shallow channels and sorted stone algal flats that are seasonally inundated occupy much of the low-lying area adjacent to the penguin colony. The habitats we sampled are more completely described by Sinclair et al. (2006a) and the soils by Hofstee et al. (2006).

Three representative sites were chosen in the 'algal flats' habitat (see Sinclair et al. 2006a) adjacent to the southeastern-most extent of the Adélie penguin colony. The 'moss patch' site $\left(72.31928^{\circ} \mathrm{S}, 170.2324^{\circ} \mathrm{E}\right)$ was in a shallow channel of fine mineral soils and sorted stony ground adjacent to a large moss (Bryum argenteum) patch. Drainage was received largely from the area south of the penguin colony, which has only longabandoned penguin mounds. The 'algal' site $\left(72.31908^{\circ} \mathrm{S}, 170.2308^{\circ} \mathrm{E}\right)$ was situated in a lowlying area along the lower reaches of the catchment, and received drainage from both inside and outside the penguin colony. The site was characterised by extensive algal and cyanobacterial growth (largely Prasiola crispa, and some Nostoc sp.) in shallow mostly standing water. The 'penguin runoff' site $\left(72.31891^{\circ} \mathrm{S}, 170.2342^{\circ} \mathrm{E}\right)$ was located in the upper part of the catchment and immediately adjacent to an active area of the penguin colony. Due to its proximity to the mounds it received the greatest penguin traffic. The soils were a mixture of fine mineral and ornithogenic soils, and supported patchily abundant Prasiola crispa.

On each sampling date, three replicates were taken from each site. Replicates were taken randomly within a ca. $5 \mathrm{~m}$ radius. We selected the three sites to represent the algal flat habitats. We did not know a priori what constituted good nematode habitat, so the sites were not biased in that regard (i.e. not chosen for high nematode density). However, the sites were not chosen totally at random but were taken to be representative of the spectrum of algal flat habitats at Cape Hallett; the only bias was that each site was different in some way (moisture, drainage, vegetation cover, penguin contact, etc.) from the other sites. Such variation would be expected from a truly random sampling.

Soil sampling was conducted as described by Sinclair et al. (2006a). Briefly, a small (average $18.9 \mathrm{~g}$ dry weight) sample of surface material and underlying soil was collected from a $2.5 \times 2.5 \mathrm{~cm}^{2}$ area to a depth of approximately $2 \mathrm{~cm}$. Surface 
vegetation was sparse, and no macroscopic algae, moss or lichen appeared in the samples. Soil samples were returned to the laboratory tent, weighed, and placed into a modified $10 \mathrm{~cm}$ Baermann funnel enclosed in pre-weighed facial tissues (see Sinclair and Sjursen 2001 for details). The samples were covered with water and left at tent temperature $\left(4-12{ }^{\circ} \mathrm{C}\right.$, no heating was available) for $14 \mathrm{~h}$. The bottom $40 \mathrm{ml}$ of water was removed from the apparatus, centrifuged and the bottom ca. $5 \mathrm{ml}$ fixed with an equal volume of boiling $8 \%$ formaldehyde. The samples were sealed in screw-cap containers, wrapped in Parafilm ${ }^{\circledR}$ and stored in a snowbank before return to New Zealand. The Baermann funnel technique was chosen because of the low technological requirements given the remote field location of this research. After extraction, the soil and tissues were dried at c. $60^{\circ} \mathrm{C}$ in a dutch oven and re-weighed to give dry weight and water content.

Microfauna in the fixed samples were counted in New Zealand, with abundances being expressed per gram dry soil. Subsequently a total of 3522 specimens were mounted in glycerol, identified and their length measured. Results for length distributions are presented and their reproductive status noted. We used $50 \mu \mathrm{m}$ length classes but, to eliminate any possible temperature-based seasonal differences in growth patterns or length, did not attempt allocation of specimens to developmental stages except to distinguish between juveniles and adults, which were separated on the basis of the presence of a vulva or spicules. Comparison of the relative proportion of adults and juveniles was made among sampling dates within sites to test for significant differences in the distribution among dates using a likelihood-ratio (G) test using PROC FREQ in SAS (Version 9.1, The SAS Institute, Cary, NC, USA). Only dates for which individuals were identified were included in the analysis.

Samples were collected in spring on 16 November 2002, when freeze-thaw cycles were still prominent (minimum temperature of -8.0 , maximum $+13.0^{\circ} \mathrm{C}$ in the $24 \mathrm{~h}$ period), and during summer on 6 December $2002\left(\min .-2.5^{\circ} \mathrm{C}\right.$, max. $\left.+11.0^{\circ} \mathrm{C}\right), 28$ December $2002\left(\min .+1.5^{\circ} \mathrm{C}\right.$, max. $\left.+9.0^{\circ} \mathrm{C}\right)$, and 18 January 2003 (min. $-1.5^{\circ} \mathrm{C}$, max. $+11.0^{\circ} \mathrm{C}$ ). The main snowmelt period was during December, and resulted in occasional inundation of the sites. However, liquid water was present during the day at the sampling sites throughout December and January. The temperature data were from a nearby data logger beneath a flat stone surface; see Sinclair et al. (2003, 2006b) for further details of temperature recording.

\section{Results}

\section{Nematode identification}

Panagrolaimus was found at all three sites. Plectus (with a modal female length in the $1001-1050 \mu \mathrm{m}$ interval) were also numerous at the moss patch site. Exceptional records include: a Plectus female $1822 \mu \mathrm{m}$ long on 18 January at the moss patch site, a single juvenile Cephalobidae $632 \mu \mathrm{m}$ long on 6 December at the penguin runoff site, and a single Plectus female $902 \mu \mathrm{m}$ long on 18 January at the penguin runoff site. Although we allocate the material to taxa recognised from continental Antarctica by Andrássy (1998) and Maslen and Convey (2006), we note some departures from the typical forms and envisage future application of molecular techniques to address questions about the identity of the nominal species involved. The occurrence of the three taxa is given in Table 1.

Panagrolaimus davidi Timm, 1971 is characterised by a prominent dorsal metastomal tooth (Timm 1971; Boström 1995) and this was present in specimens from all three sites. Mature specimens had, in addition, prominent vulval lips as described for P. magnivulvatus Boström, 1995. Vulva lips appear somewhat variable in Antarctic nematodes, with prominent vulval lips being illustrated in Scottnema lindsayae by Andrássy (1998) and while Timm (1971) mentions protuberant vulval lips his Figure $1 \mathrm{~A}$ is quite unlike that of Andrássy. $P$. davidi is associated with coastal sites and in particular penguin colonies and ornithogenic soils (Wharton 2003), and Brown et al. (2004) give the temperature threshold for development as $7.6^{\circ} \mathrm{C}$. Our adult specimens typically had lengths in the range of $750-1100 \mu \mathrm{m}$, although the longest was $1655 \mu \mathrm{m}$. Published adult lengths for $P$. davidi are $730-990 \mu \mathrm{m}$ (individuals; Timm 1971) and 772-950 $\mu \mathrm{m}$ (populations; Wharton 1998). Sohlenius (1988) demonstrated some Panagrolaimus spp. exhibit a range of adult body length, reflecting nutrition, as affected by culture age, increasing from a mean of $910-1014 \mu \mathrm{m}$ after 19-21 days culture and then declining to $585 \mu \mathrm{m}$ after 68 days. These data show a factor of $1.7 \times$, comparable with that of $2.2 \times(750-1655 \mu \mathrm{m})$ for the present data. Data for some other bacterial-feeding nematodes show a similar effect of food supply on length distribution (e.g., Sohlenius 1973).

Following Andrássy (1998), Maslen and Convey (2006) list Plectus frigophilus Kirjanova, 1958 and P. murrayi Yeates, 1970 as the only Plectus spp. from continental Antarctica. Measurements tabulated in Andrássy, 1998 give female length ranges 


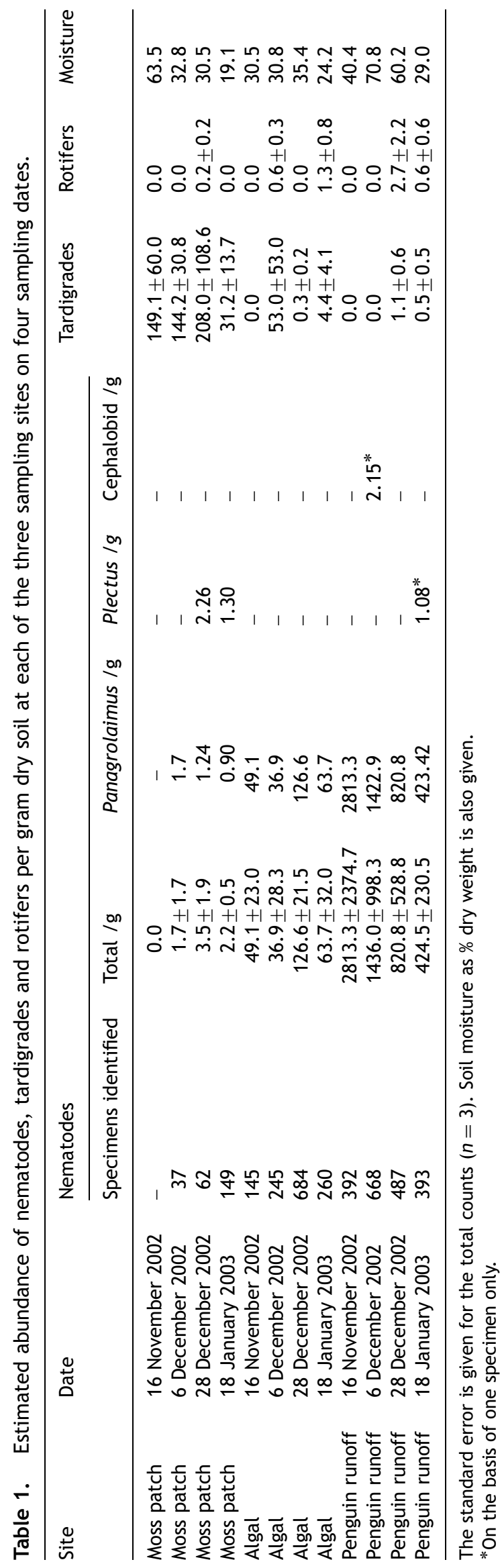

for them of $1190-2060 \mathrm{~mm}$ and $600-1190 \mu \mathrm{m}$, respectively. The Plectus females collected on 29 December were 874-1161 $\mu \mathrm{m}$, while those collected on 18 January were $885-1161 \mu \mathrm{m}$ plus an outlier at $1822 \mu \mathrm{m}$ (Figure 1). On morphological grounds (amphid position, egg length, tail shape, 'spur' caudal seta) we allocate our material to $P$. murrayi, and including the $1822 \mu \mathrm{m}$ long female. While the latter lacked the characteristic bent tail and the uterine egg was $<1$ body width these characters are considered to reflect the greater body size.

The juvenile cephalobid could not be identified, but was certainly not Scottnema lindsayae Timm, 1971 a species associated with dry and saline soils (Wharton 2003).

\section{Nematode abundance}

The abundance of nematodes and other soil microfauna in each sample is given in Table 1, together with soil moisture content. The penguin runoff site showed the greatest nematode abundance, averaging 1374/g soil over the four sampling dates, although it declined during the sampling programme. In contrast, the algal and moss patch sites averaged 69.1 and $1.9 / \mathrm{g}$ soil, respectively and had their maximum abundance on 28 December. Only the moss patch site, which had fewest nematodes, had significant numbers of two species with Panagrolaimus averaging $0.96 / \mathrm{g}$ soil and Plectus $0.89 / \mathrm{g}$ soil.

\section{Length distributions}

No nematodes were recovered from the first sampling of the moss patch site, and there were few at the second sampling on 6 December (Figure 1). This site had mixed populations of Panagrolaimus and Plectus, but together they did not reach the same abundance as the two sites with Panagrolaimus alone. On 6 December, the Panagrolaimus population recovered included only $30 \%$ juveniles, while on 29 December it was exclusively adult females, including the longest specimens $(1328 \mu \mathrm{m})$ (Figure 1). On 18 January, $59 \%$ of Panagrolaimus were juveniles, including the smallest specimen $(339 \mu \mathrm{m})$. Plectus was only recovered on 29 December when $20 \%$ were juveniles and 18 January when $63 \%$ were juveniles. On 29 December, the length of females was fairly normally distributed with the 1001-1050 $\mu \mathrm{m}$ interval having most specimens and the longest being $1161 \mu \mathrm{m}$. On 18 January, there was again a group of females 

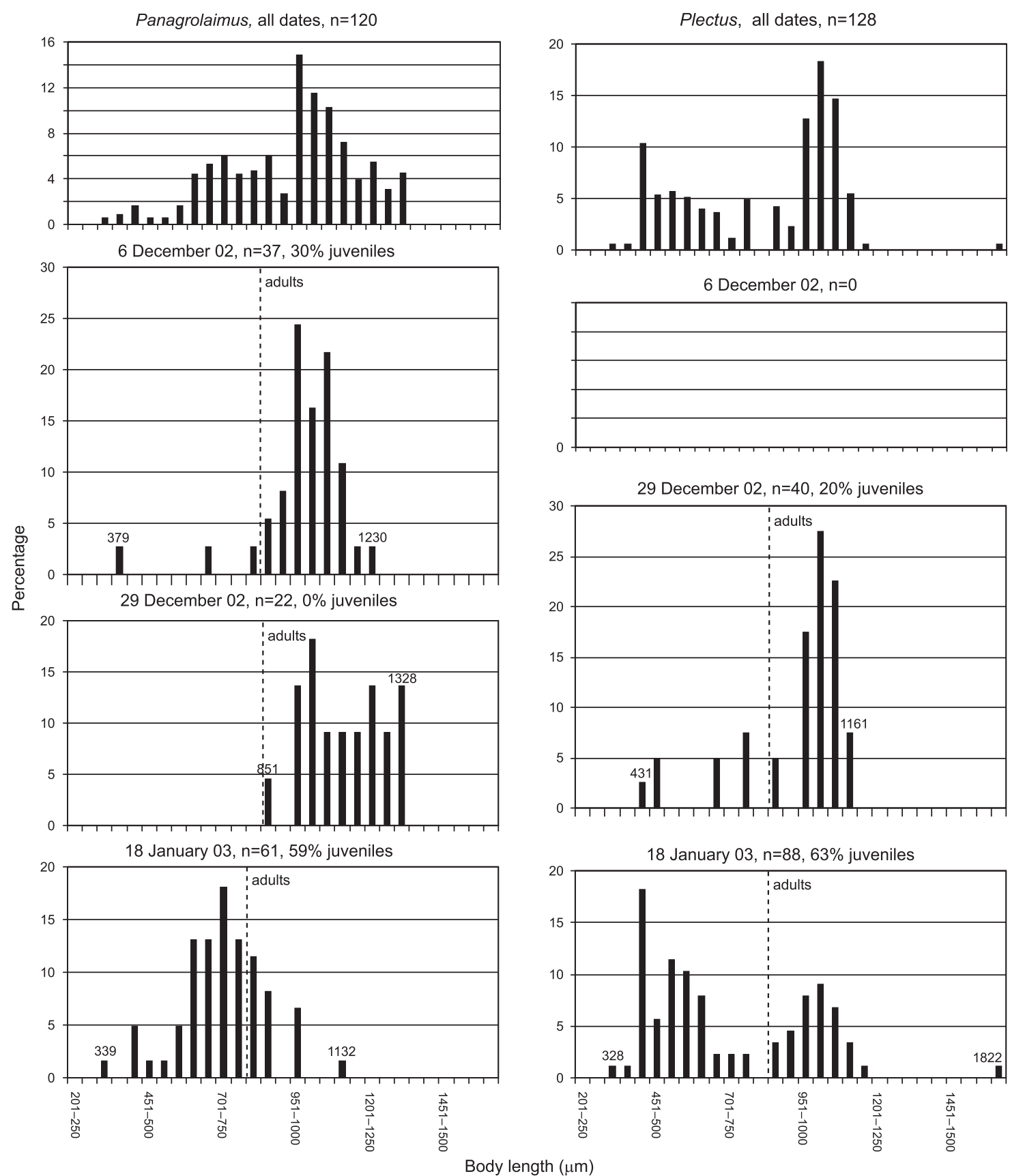

Figure 1. Length distribution, in $50 \mu \mathrm{m}$ intervals, of nematodes from a moss patch in the Cape Hallett penguin colony, both overall and on four sampling dates in the 2002-2003 summer. No nematodes were recovered on 16 November but for each of the subsequent three sampling dates the total number of specimens identified, the percentage of specimens that were juveniles are given, the length of the smallest and longest individuals are shown, and all specimens to the right of vertical line were adult. Both Panagrolaimus davidi and Plectus murrayi were identified from the site.

centred on the 1001-1050 $\mu \mathrm{m}$ interval, but also one female $1822 \mu \mathrm{m}$ long (Figure 1).

At the algal site only Panagrolaimus was detected and on the first sampling date, 16 November 2002, there were $4 \%$ in the shortest size class $(250-300 \mu \mathrm{m}), 7 \%$ or $8 \%$ in the $401-450$ and $451-500 \mu \mathrm{m}$ classes, $8 \%$ or $9 \%$ in the two classes immediately below adults and the longest female was $1184 \mu \mathrm{m}$ (Figure 2 - 16 November). In total, 55\% of specimens were juveniles. At the second sampling $<1 \%$ were shorter than $350 \mu \mathrm{m}$, the longest female $1184 \mu \mathrm{m}$ and only $46 \%$ of 245 specimens were juvenile (Figure 2 - 6 December). On 29 December the trend to longer specimens was 
Panagrolaimus, all dates, $\mathrm{n}=1334$

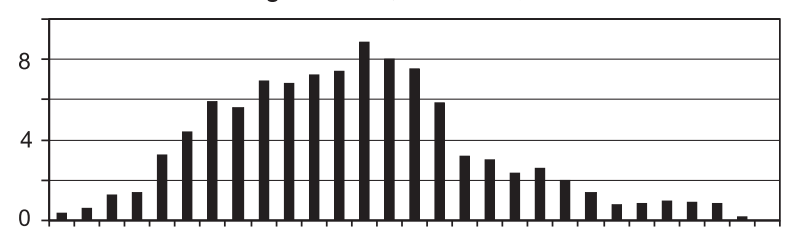

16 November $02, n=145,55 \%$ juveniles

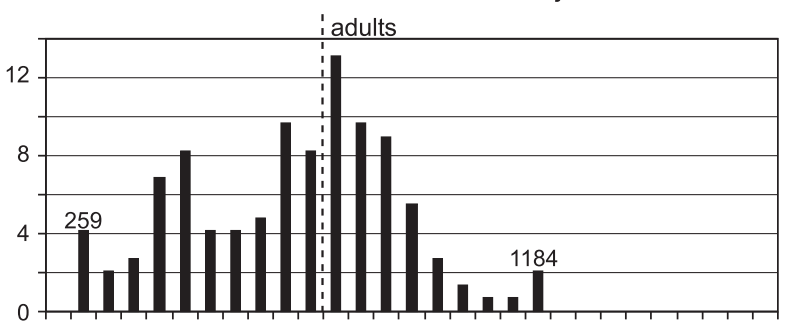

6 December 02, $n=245,46 \%$ juveniles

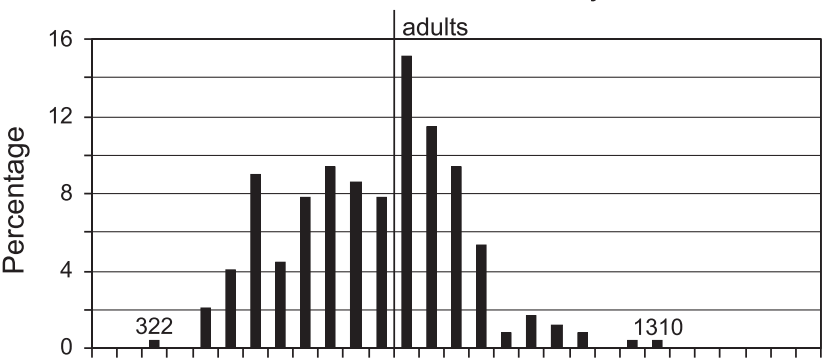

29 December 02, $n=684,42 \%$ juveniles

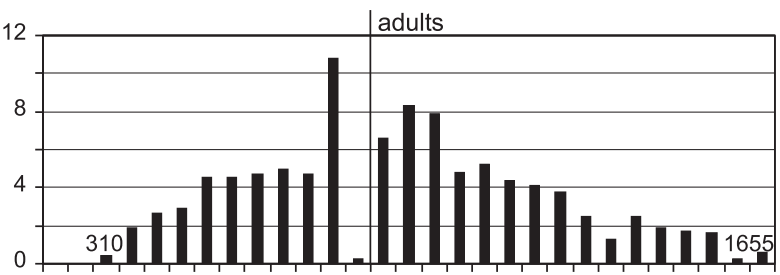

18 January $03, n=260,73 \%$ juveniles

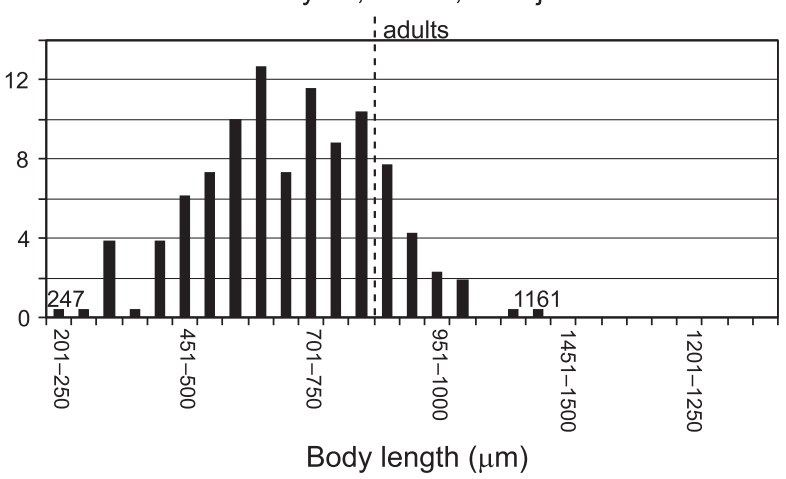

Figure 2. Length distribution, in $50 \mu \mathrm{m}$ intervals, of nematodes from the algal site in the Cape Hallett penguin colony, both overall and on four sampling dates in the 2002-2003 summer. For each of the four sampling dates the total number of specimens identified, the percentage of specimens that were juveniles are given, the length of the smallest and longest individuals are shown, and all specimens to the right of vertical line were adult. Only Panagrolaimus davidi was identified from the site. 
Panagrolaimus, all dates, $\mathrm{n}=1938$

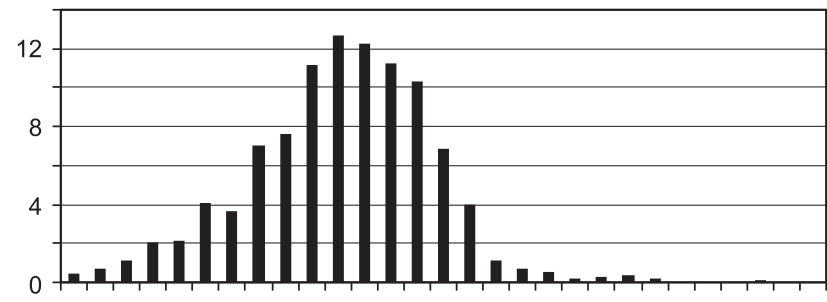

16 November 02, $n=392,74 \%$ juveniles
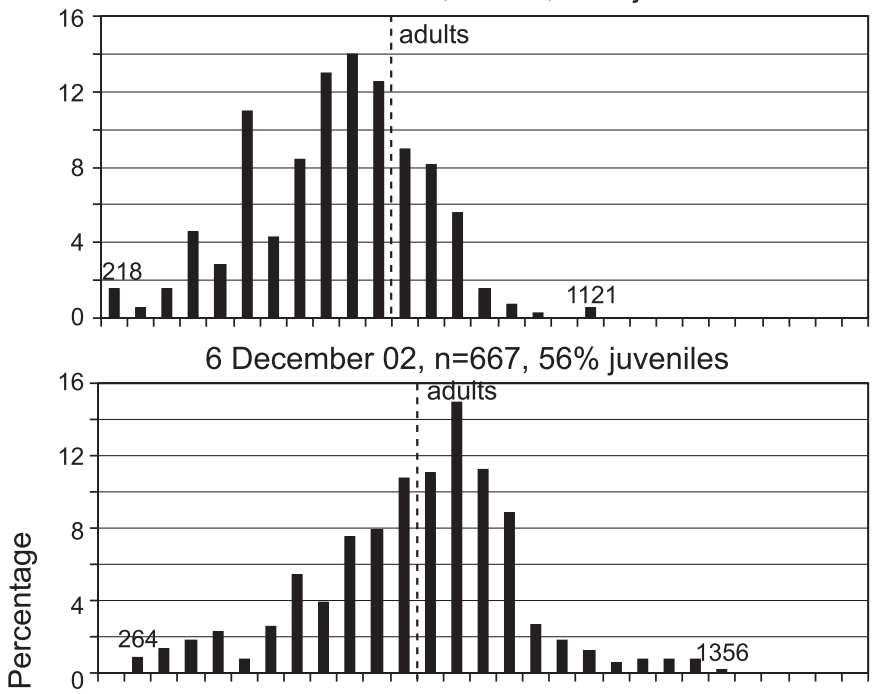

29 December 02, n=487, 35\% juveniles

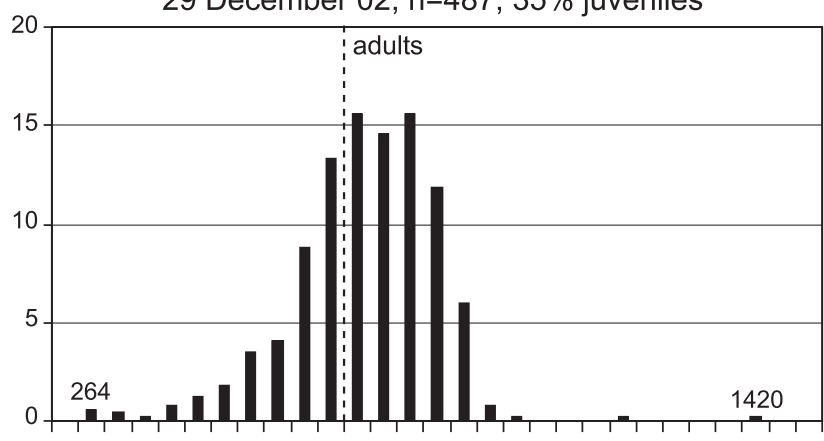

18 January 03, n=392, 49\% juveniles

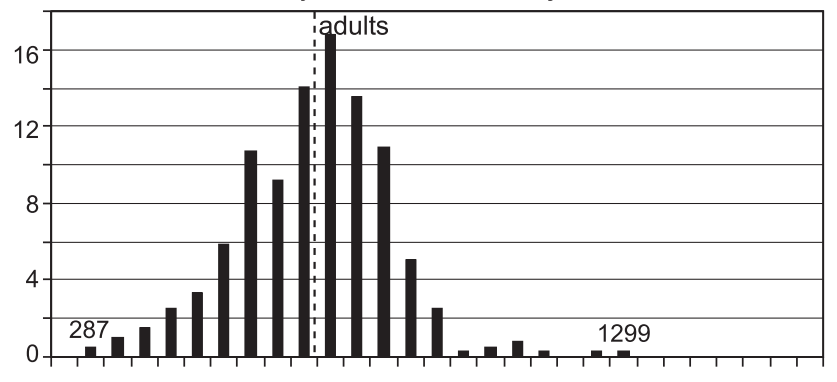

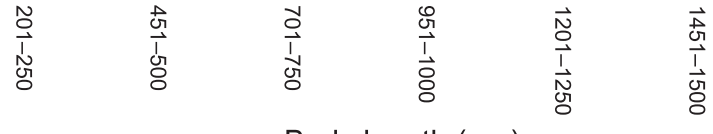

Body length $(\mu \mathrm{m})$

Figure 3. Length distribution, in $50 \mu \mathrm{m}$ intervals, of nematodes from the penguin runoff site in the Cape Hallett penguin colony, both overall and on four sampling dates in the 2002-2003 summer. For each of the four sampling dates the total number of specimens identified, the percentage of specimens that were juveniles are given, the lengths of the smallest and longest individuals are shown, and all specimens to the right of vertical line were adult. In total 1938 Panagrolaimus davidi specimens were identified from the site, plus a juvenile cephalobid (6 December) and a female Plectus (18 January). 
continued with the longest female being $1655 \mu \mathrm{m}$ and only $42 \%$ were juveniles. There was, however, a marked reduction in the proportion in the length class immediately before adults (i.e., $801-850 \mu \mathrm{m}$ ) leading to a somewhat bimodal distribution pattern (Figure 2-29 December). The final sampling, on 18 January gave the greatest percentage of juveniles found at this site $(73 \%)$, the smallest juvenile found $(247 \mu \mathrm{m})$ and the lowest maximum adult length $(1161 \mu \mathrm{m})$ (Figure $2-18$ January). Thus initially the length distribution shifted to the right, and the percentage of juveniles decreased, but from 29 December maturation, that is recruitment to adults, appears to have slowed and the length distribution shifted to smaller individuals at the last sampling.

The penguin runoff site also had only Panagrolaimus and the length distribution showed similar trends to those at algal site. Also, the percentage of juveniles decreased across the first three sampling dates $(74 \%, 56 \%$ and $35 \%)$ before increasing to $46 \%$ on 18 January (Figure 3 ). As at the penguin runoff site there was an initial, slight, peak in the shortest size class $(218 \mu \mathrm{m})$ but on the subsequent three sampling the smallest specimens fell into the 251-300 $\mu \mathrm{m}$ length class. The longest females $(1420 \mu \mathrm{m})$ were again found on 29 December (Figure 3 - 29 December).

The proportion of individuals identified as juveniles varied significantly with sampling date in all sites and samples in which Panagrolaimus was abundant (algal: $G=77.65$, df $=3, p<0.001$, runoff: $G=40.34, \mathrm{df}=3, p<0.001$, moss: $G=41.29$, $\mathrm{df}=2, p<0.001)$ and for Plectus at the moss site (the only site where it was abundant; $G=21.58$, $\mathrm{df}=1, \quad p<0.001)$, suggesting that we were observing the movement of cohorts through the population, rather than changes attributable to sampling error.

\section{Discussion}

The primary aim of the sampling was to assess temporal variation in the nematode fauna. At each of the three sampling sites the progression of size cohorts and the proportion of adults: juveniles is such that we conclude that most of the dominant nematodes completed a full life cycle during the sampling period. While the sampling programme was limited to the period that the collectors were present at Cape Hallett, the size distributions suggest that only a single generation would have been feasible during the summer. However, the magnitude of the population changes indicate marked increases in nematode biomass and thus a significant contribution to soil processes through microbial grazing, nematode metabolism and excretion.

While nematode life cycles are temperaturedependent (e.g., 5.5 days at $15^{\circ} \mathrm{C}, 3.5$ days at $20^{\circ} \mathrm{C}$ and 2.5 days at $25^{\circ} \mathrm{C}$ for Caenorhabditis elegans) (Wood 1988), they are also affected by resource availability. Both Overhoff et al. (1993) and Porazinska et al. (2002b) suggested that Scottnema lindsayae requires perhaps 20 years to complete a reproductive cycle in the Victoria Land Dry Valleys. This reflects not only a long generation time even under favourable conditions $\left(218\right.$ days at $10^{\circ} \mathrm{C}$ ) (Overhoff et al. 1993), but also the 'desert' conditions in the Dry Valleys where, in addition to low temperature, a lack of free water inhibits biological activity. Free water was available for much of the summer at Cape Hallett on an almost daily basis, so at this more northern location the limiting factor of water appears to be removed. Sinclair et al. (2006b) measured microclimate temperatures beneath thin stones ca. $30 \mathrm{~m}$ from the site of the present study during December 2006 (their 'Cryptopygus' site). Over the month of December, they report $556.6 \mathrm{~h}$ above $0^{\circ} \mathrm{C}$, nearly $75 \%$ of the available time, and free water was available for this entire period (B.J. Sinclair, unpubl. obs.). Cape Hallett is not only slightly warmer than the Dry Valleys (Howard-Williams et al. 2006), but it also appears that the nematodes at Hallett develop faster than has been predicted for S. lindsayae. In temperate moist climates, generation times of nematodes under field conditions may be as short as a matter of days for bacterial-feeding Rhabditidae similar to $C$. elegans while some species of plant-feeding Xiphinema and Longidorus (Dorylaimida) reproduce once in a year (Flegg 1966; Yeates et al. 2008).

Although the duration of nematode activity is governed by temperature, both directly and through its effect on the availability of free water, it is clear that nematode activity at Cape Hallett is greater than in the Dry Valleys and thus the potential nematodes' contribution to soil processes is greater. The microbial resource available to the nematodes near the Adélie penguin colony is presumably significantly greater than in the Dry Valleys due to both higher water availability and marine-sourced nutrient inputs. While there are bacterial-feeding nematodes with shorter generation times than Panagrolaimus and Plectus, the diurnal, and indeed intra-day, variations in temperature (see Sinclair et al. 2003), in particular the freeze-thaw cycles must restrict the nematode assemblage to taxa able to withstand such conditions. However, such freeze-thaw is not uncommon 
in cool temperate climates (Geiger 1965), and nematodes can be highly cold-tolerant in Antarctic and other habitats (Wharton 2003; Smith et al. 2008), so nematode survival of these conditions (and the much colder winter; Pryor 1962) is not without precedent.

The Plectus and Panagrolaimus populations assessed have generation times typical of members of the Plectidae and Panagrolaimidae from temperate climates. That Scottnema has a much longer life cycle than other members of the Cephalobidae (Porazinska et al. 2002b) suggests that it does represent a specific adaptation to (or constraint by) the environmental conditions of continental Antarctica as described by Convey (1996).

The nematode fauna varied across the three sites. While the microhabitats sampled differed, they were all in the same general area, received surface water during the summer months, and were adjacent to an extensive area of nesting Adélie penguins. Thus, differences in nematode fauna may be attributed to differences in algae abundance, associated microbes and the extent of direct nutrient runoff from the penguin colony. All the nematodes are regarded as bacterial-feeding with no predators or omnivores detected.

It is remarkable that just one of the 3522 nematodes identified belonged to Cephalobidae. Not only does it indicate the problem in determining the number of species at a locality and in the application of species discovery curves (Bebber et al. 2007) at even a local scale but also is congruent with Sohlenius et al. (2004) who questioned whether some rare nematodes on Antarctic nunataks should be regarded as established in Antarctica. Given the differences among the assemblages at the three present sites we consider that initial conditions at the beginning of the summer determine which genera will develop at a particular site and that depending on the site and year more comprehensive sampling could yield sites at which Cephalobidae achieve significant populations and contribute more to soil processes.

The distribution of Plectus is in accordance with Andrássy (1998), who noted that $P$. murrayi seems to prefer moss-covered soils. We recorded a single large Plectus female $(L=1822 \mu \mathrm{m})$, which is outside the normal range for $P$. murrayi given by Andrássy (1998). In Panagrolaimus we found a somewhat extended length range in adults (especially females). In the absence of correspondingly large juveniles we attribute this to some form of 'delayed mortality' or adult 'persistence'. The larger size of some individuals might also reflect better growing conditions than at the sites from which Andrássy's (1998) samples were collected. Although Tardigrada, which may prey upon nematodes are common in Antarctic soils, including the present samples, and mites may also prey upon nematodes, there are few records of nematodetrapping fungi from continental Antarctica (Tosi et al. 2001; Adams et al. 2006) and while other decomposing and degrading agents (e.g. chitinases) are common in continental Antarctic (e.g., Fenice et al. 1998; Xiao et al. 2005) their overall effective activity may be low, allowing increased longevity and growth of nematodes.

Table 2. Abundance of microfauna/g dry soil at selected sites reported in four studies from continental Antarctica.

\begin{tabular}{|c|c|c|c|c|c|}
\hline Location & Sample/site detail & Nematodes & Tardigrades & Rotifers & Reference \\
\hline Cape Bird Adélie colony & January 1991 & 0.171 & - & - & Porazinska et al. (2002a) \\
\hline Cape Bird Adélie colony & December 1994 & 0.890 & - & 1.476 & Porazinska et al. (2002a) \\
\hline Cape Crozier Adélie colony & January 1995 & - & - & 0.121 & Porazinska et al. (2002a) \\
\hline Cape Crozier Adélie colony & December 1995 & - & - & 0.990 & Porazinska et al. (2002a) \\
\hline Cape Crozier Adélie colony & December 1997 & 0.550 & 0.042 & 0.279 & Porazinska et al. (2002a) \\
\hline Cape Royds Adélie colony & January 1990 & 0.918 & 0.498 & - & Porazinska et al. (2002a) \\
\hline Cape Royds Adélie colony & January 1994 & 0.001 & - & 0.008 & Porazinska et al. (2002a) \\
\hline Cape Royds Adélie colony & December 1994 & 0.001 & - & 0.581 & Porazinska et al. (2002a) \\
\hline Cape Royds Adélie colony & November 1995 & - & - & - & Porazinska et al. (2002a) \\
\hline Taylor Valley (3 dates) & Exposed site & 1.105 & - & 0.085 & Gooseff et al. (2003) \\
\hline Taylor Valley (3 dates) & 3 subnivian sites & 1.649 & 0.037 & 2.069 & Gooseff et al. (2003) \\
\hline $\begin{array}{l}\text { Cape Hallett Adélie colony } \\
\text { ( } 4 \text { dates) }\end{array}$ & $\begin{array}{l}\text { Moss patch- } \\
\text { Panagrolaimus+Plectus }\end{array}$ & 1.900 & 133.100 & 0.050 & Present study \\
\hline $\begin{array}{l}\text { Cape Hallett Adélie colony } \\
\text { (4 dates) }\end{array}$ & Algal-Panagrolaimus dominant & 69.100 & 14.400 & 0.475 & Present study \\
\hline $\begin{array}{l}\text { Cape Hallett Adélie colony } \\
\text { ( } 4 \text { dates) }\end{array}$ & $\begin{array}{l}\text { Penguin runoff-Panagrolaimus } \\
\text { dominant }\end{array}$ & 1374.000 & 0.400 & 0.375 & Present study \\
\hline $\begin{array}{l}\text { East Antarctic nunataks } \\
\text { (14 sites) }\end{array}$ & Plectus dominant & 275.500 & 17.540 & 28.640 & Sohlenius and Boström (2009) \\
\hline $\begin{array}{l}\text { East Antarctic } \\
\text { nunataks ( } 6 \text { sites) }\end{array}$ & Panagrolaimus dominant & 1165.300 & 2.220 & 742.000 & Sohlenius and Boström (2009) \\
\hline
\end{tabular}


The fact that we did not record the widely studied Scottnema lindsayae Timm, 1971 and Eudorylaimus antarcticus (Steiner, 1916) Yeates, 1970 in samples probably reflects the 'enriched' conditions around the penguin colony. Barrett et al. (2006) recorded Eudorylaimus sp. and Plectus antarcticus from moss-dominated soils at Willett Cove at Cape Hallett but did not recover $S$. lindsayae from there or abandoned penguin colonies of nearby SeeBee Spit. The fact that the Baermann funnel extraction process we used under field conditions is less efficient than other methods (e.g. density gradient centrifugation; Freckman and Virginia 1993) may explain the failure to detect Eudorylaimus sp. in our samples as environmental conditions may not have been suitable. Ongoing studies will assess the distribution of nematode taxa over a wider area of Cape Hallett.

The three present sites varied in their average nematode abundance from 1.9 to 1374 nematodes/ g dry soil. Table 2 compares soil microfaunal abundance in four selected studies from continental Antarctica. In each study microfaunal abundance was highly aggregated, reflecting site (patch) specific conditions. For example among the Eastern Antarctica samples highest abundances of Plectus were generally found close to the rim of ice along the border of nunatak where the soil was rather moist due to melting snow and ice. In contrast, high abundances of Panagrolaimus were typically found in ornithogenic soils. The differences among abundances per gram soil highlight the spatial variability of soil biota in continental Antarctica on both small and large scales, and are reflected in the differences among the sites we sampled.

\section{Conclusion}

Samples from three sites in the Cape Hallett Adélie Penguin breeding colony have clearly demonstrated that bacterial-feeding nematodes have an annual life cycle in continental Antarctic. Moderate temperatures and regular presence of free water underlie this biological activity, which contrasts with estimates of up to 20 years for a generation of Scottnema in the Victoria Land Dry Valleys. Plectus murrayi and Panagrolaimus davidi were overwhelmingly dominant in the Cape Hallett samples. A single specimen of Cephalobidae was recovered. Nematode abundance ranged from 2 to $1375 / g$ soil, which is greater than in many Antarctic soils, although similar densities have been recorded around nunataks.

\section{Acknowledgements}

Antarctic fieldwork was supported by Antarctica New Zealand, the South African National Antarctic Programme, the New Zealand Foundation for Research, Science and Technology and Stellenbosch University. The Italian National Antarctic Research Programme, Quark Expeditions, Helicopters New Zealand, the crew of the Kapitan Khlebnikov and First Ascent provided valuable logistic support. We are grateful to members of the (then) Zoology Department at University of Stellenbosch and Botany Department at Otago University for technical support. BJS and MBS thank Jaco Klok and John Terblanche for assistance, company and discussions in the field. Nicolette Faville prepared the figures.

\section{References}

Adams, B.J., Bardgett, R.D., Ayres, E., Wall, D.H., Aislabie, J., Bamforth, S., Bargagli, R., Cary, C., Cavacini, P., Connell, L., Convey, P., Fell, J.W., Frati, F., Hogg, I.D., Newsham, K.K., O’Donnell, A., Russell, N., Seppelt, R.D., Stevens, M.I., 2006. Diversity and distribution of Victoria Land biota. Soil Biol. Biochem. 38, 3003-3018.

Andrássy, I., 1998. Nematodes in the sixth continent. J. Nem. Morphol. Syst. 1, 107-186.

Barrett, J.E., Virginia, R.A., Wall, D.H., Cary, S.C., Adams, B.J., Hacker, A.L., Aislabie, J.M., 2006. Covariation in soil biodiversity and biogeochemistry in northern and southern Victoria Land, Antarctica. Antarct. Sci. 18, 535-548.

Barrett, J.E., Virginia, R.A., Wall, D.H., Adams, B.J., 2008a. Decline in a dominant invertebrate species contributes to altered carbon cycling in a lowdiversity soil ecosystem. Glob. Change Biol. 14, 1734-1744.

Barrett, J.E., Virginia, R.A., Wall, D.H., Doran, P.T., Fountain, A.G., Welch, K.A., Lyons, W.B., 2008b. Persistent effects of a discrete warming event on a polar desert ecosystem. Glob. Change Biol. 14, 2249-2261.

Bebber, D.P., Marriott, F.H.C., Gaston, K.J., Harris, S.A., Scotland, R.W., 2007. Predicting unknown species numbers using discovery curves. Proc. R. Soc. B 274, 1651-1658.

Boström, S., 1995. Populations of Plectus acuminatus Bastian, 1865 and Panagrolaimus magnivulvatus n. sp. (Nematoda) from nunatakks in Dronning Maud Land, East Antarctica. Fundam. Appl. Nematol. 18, 25-34.

Brown, I.M., Wharton, D.A., Millar, R.B., 2004. The influence of temperature on the life history of the Antarctic nematode Panagrolaimus davidi. Nematology 6, 883-890.

Burn, A.J., 1984. Life cycle strategies in two Antarctic Collembola. Oecologia 64, 223-229. 
Chown, S.L., Convey, P., 2007. Spatial and temporal variability across life's hierarchies in the terrestrial Antarctic. Philos. Trans. R. Soc. B 362, 2307-2331.

Convey, P., 1996. The influence of environmental characteristics on life history attributes of Antarctic terrestrial biota. Biol. Rev. 71, 191-225.

Fenice, M., Selbmann, L., Di Giambattista, R., Federici, F., 1998. Chitinolytic activity at low temperature of an Antarctic strain (A3) of Verticillium lecanii. Res. Microbiol., 289-300.

Flegg, J.J.M., 1966. Once-yearly reproduction in Xiphinema vuittenezi. Nature London 212, 741.

Freckman, D.W., Virginia, R.A., 1993. Extraction of nematodes from Dry Valley Antarctic soils. Polar Biol. 13, 483-487.

Freckman, D.W., Mankau, R., Ferris, H., 1975. Nematode community structure in desert soils: nematode recovery. J. Nematol. 7, 343-346.

Geiger, R., 1965. The Climate Near the Ground. Harvard University Press, Cambridge.

Gooseff, M.N., Barrett, J.E., Doran, P.T., Fountain, A.G., Lyons, W.B., Parsons, A.N., Porazinska, D.L., Virginia, R.A., Wall, D.H., 2003. Snow-patch influence on soil biogeochemical processes and invertebrate distribution in the McMurdo Dry Valleys, Antarctica. Arct. Antarct. Alp. Res. 35, 91-99.

Hofstee, E.H., Balks, M.R., Petchey, F., Campbell, D.I., 2006. Soils of Seabee Hook, Cape Hallett, north Victoria Land, Antarctica. Antarct. Sci. 18, 473-486.

Howard-Williams, C., Peterson, D., Lyons, W.B., Cattaneo-Vietti, R., Gordon, S., 2006. Measuring ecosystem response in a rapidly changing environment: the latitudinal gradient project. Antarct. Sci. 18, 465-471.

Janetschek, H., 1967. Growth and maturity of the springtail, Gomphiocephalus hodgsoni Carpenter, from South Victoria Land and Ross Island. In: Gressitt, J.L. (Ed.), Entomology of Antarctica. American Geophysical Union, Washington, DC, pp. 295-305.

Kennedy, A.D., 1993. Water as a limiting factor in the Antarctic terrestrial environment: a biogeographical synthesis. Arct. Alp. Res. 25, 308-315.

Maslen, N.R., Convey, P., 2006. Nematode diversity and distribution in the southern maritime Antarctic- clues to history? Soil Biol. Biochem. 38, 3141-3151.

Moorhead, D.L., Wall, D.H., Virginia, R.A., Parsons, A.N., 2002. Distribution and life-cycle of Scottnema lindsayae (Nematoda) in Antarctic soils: a modeling analysis of temperature responses. Polar Biol. 25, 118-125.

Overhoff, A., Freckman, D.W., Virginia, R.A., 1993. Lifecycle of the microbivorous Antarctic Dry Valley nematode Scottnema lindsayae (Timm, 1971). Polar Biol. 13, 151-156.

Porazinska, D.L., Wall, D.H., Virginia, R.A., 2002a. Invertebrates in ornithogenic soils on Ross Island, Antarctica. Polar Biol. 25, 569-574.

Porazinska, D.L., Wall, D.H., Virginia, R.A., 2002 b. Population age structure of nematodes in the
Antarctic Dry Valleys: perspectives on time, space and habitat suitability. Arct. Antarct. Alp. Res. 34, 159-168.

Pryor, M.E., 1962. Some environmental features of Hallett Station, Antarctica, with special reference to soil arthropods. Pac. Insects 4, 681-728.

Pugh, P.J.A., Convey, P., 2008. Surviving out in the cold: Antarctic endemic invertebrates and their refugia. J. Biogeogr. 35, 2176-2186.

SCAR (Scientific Committee on Antarctic Research), 2003. Management Plan for Specially Protected Area (SPA) No. 7 Cape Hallett, Northern Victoria Land, Ross Sea. SCAR Bulletin 148, January 2003. 〈http://www.scar. org/publications/bulletins/148/aspa106/ $\rangle$ [accessed 12 September 2008]

Sinclair, B.J., 2001. On the distribution of terrestrial invertebrates at Cape Bird, Ross Island, Antarctica. Polar Biol. 24, 394-400.

Sinclair, B.J., Sjursen, H., 2001. Terrestrial invertebrate abundance across a habitat transect in Keble Valley, Ross Island, Antarctica. Pedobiologia 45, 134-145.

Sinclair, B.J., Klok, C.J., Scott, M.B., Terblanche, J.S., Chown, S.L., 2003. Diurnal variation in supercooling points of three species of Collembola from Cape Hallett, Antarctica. J. Insect Physiol. 49, 1049-1061.

Sinclair, B.J., Scott, M.B., Klok, C.J., Terblanche, J.S., Marshall, D.J., Reyers, B., Chown, S.L., 2006 a. Determinants of terrestrial arthropod community composition at Cape Hallett, Antarctica. Antarct. Sci. 18, 303-312.

Sinclair, B.J., Terblanche, J.S., Scott, M.B., Blatch, G.L., Klok, C.J., Chown, S.L., 2006b. Environmental physiology of three species of Collembola at Cape Hallett, North Victoria Land, Antarctica. J. Insect Physiol. 52, 29-50.

Smith, T., Wharton, D.A., Marshall, C.J., 2008. Cold tolerance of an Antarctic nematode that survives intracellular freezing: comparisons with other nematode species. J. Comp. Physiol. B 187, 93-100.

Sohlenius, B., 1973. Influence of food supply on population structure and length distribution in Acrobeloides nanus (Nematoda: Cephalobidae). Pedobiologia 13, 205-213.

Sohlenius, B., 1988. Interactions between two species of Panagrolaimus in agar cultures. Nematologica 34, 208-217.

Sohlenius, B., Boström, S., 2009. Distribution and population structure of two bacterial feeding nematode genera in ice-free areas in East Antarctica. Nematology in press.

Sohlenius, B., Boström, S., Jönsson, K.I., 2004. Occurrence of nematodes, tardigrades and rotifers on ice-free areas in East Antarctica. Pedobiologia 48, 395-408.

Spaull, V.W., 1973. Seasonal variation in numbers of soil nematodes at Signy Island, South Orkney Islands. Br. Antarct. Surv. Bull. 33\&34, 47-56. 
Timm, R.W., 1971. Antarctic soil and freshwater nematodes from the McMurdo Sound Region. Proc. Helminthol. Soc. Wash. 38, 42-52.

Tosi, S., Annovazzi, L., Tois, I., ladadola, P., Caretta, G., 2001. Collagenase production in an Antarctic strain of Arthrobotrys tortor Jarowaja. Mycopathologia 153, 157-162.

Treonis, A.M., Wall, D.H., Virginia, R.A., 2002. Field and microcosm studies of decomposition and soil biota in a cold desert soil. Ecosystems 5, 159-170.

Wall, D.H., Adams, B.J., Barrett, J.E., Hopkins, D.W., 2006. A synthesis of soil biodiversity and ecosystem functioning in Victoria Land, Antarctica. Soil Biol. Biochem. 38, 3001-3002.

Wharton, D.A., 1998. Comparison of the biology and freezing tolerance of Panagrolaimus davidi, an Antarctic nematode, from field samples and cultures. Nematologica 44, 643-653.

Wharton, D.A., 2003. The environmental physiology of Antarctic terrestrial nematodes: a review. J. Comp. Physiol. B 173, 621-628.

Wharton, D.A., Barclay, S., 1993. Anhydrobiosis in the free-living Antarctic nematode Panagrolaimus davidi. Fundam. Appl. Nematol. 16, 17-22.
Wood, W.B. (Ed.), 1988. The Nematode Caenorhabditis elegans. Cold Spring Harbor monograph series 17. Cold Spring Harbor, NY.

Womersley, C.Z., Wharton, D.A., Higa, L.M., 1998. Survival. In: Perry, R.N., Wright, D.J. (Eds.), The Physiology and Biochemistry of Free-Living and Plant-Parasitic Nematodes. CABI, Wallingford, UK, pp. 217-320.

Xiao, X., Yin, X., Lin, J., Sun, L., You, Z., Wang, P., Wang, F., 2005. Chitinase genes in lake sediments of Ardley Island, Antarctica. Appl. Environ. Microbiol. 71, 7904-7909.

Yeates, G.W., 1970. Two terrestrial nematodes from the McMurdo Sound Region, Antarctica, with a note on Anaplectus arenicola Killick, 1964. J. Helminthol. 44, 27-34.

Yeates, G.W., Mercer, C.F., Newton, P.C.D., 2008. Populations of Longidorus elongatus (Nematoda: Longidoridae) in two New Zealand soils under grazed pasture. N.Z. J. Zool. 35, 287-296.

Yeates, G.W., Ferris, H., Moens, T., van der Putten, W.H., 2009. The role of nematodes in ecosystems, In: Wilson, M., Kakouli-Duarte, T., (Eds.), Nematodes as Environmental Bioindicators, CABI, Wallingford, UK, in press. 